\title{
Mitologia Cananeia: a figura de Baal e seu culto no "mito de Baal" de Ugarit
}

Orientadora: Profa. Maria de Lourdes Corrêa Lima

Pesquisadora: Quézia de Melo Souza

Fonte: $\mathrm{CNPq}$

\section{Introdução}

Através dos textos mitológicos encontrados em Ugarit, atual Ras Shamra, é possível compreender a substância de fé de civilizações que floresceram nessa região da Síria no segundo milênio a.C. Nessa perspectiva, o trabalho aqui apresentado tomou como objeto de estudo, particularmente, os textos do Ciclo de Baal, relevante divindade da região.

\section{Objetivos}

O objetivo geral do projeto é descrever a figura de Baal e seu culto tal como são apresentados nos textos de Ugarit.

Os objetivos específicos são: Conhecer a civilização e o conjunto literário mitológico de Ugarit e avaliar sua importância para compreensão da religião cananeia, localizar a figura de Baal dentro do panteão ugarítico e descrever suas funções segundo a mitologia cananeia expressa no Ciclo de Baal e explicitar os principais elementos do culto a Baal segundo os textos de Ugarit estudados. 